\title{
EXECUTIVE/LEGISLATIVE RELATIONSHIP IN BAYELSA STATE UNDER GOVERNOR HENRY SERIAKE DICKSON'S ADMINISTRATION: ISSUES AND CHALLENGES
}

\author{
${ }^{1}$ Okoko Sinizibe \\ Department of Public Administration, Bayelsa State Polytechnic, Aleibiri. \\ ${ }^{2}$ Ogbomah, Oyin-Emi Frank \\ Department of Public Administration, Bayelsa State Polytechnic, Aleibiri.
}

\section{${ }^{3}$ Kakatei Juanita}

Department of Business Administration and Management, Bayelsa State Polytechnic,

$$
\text { Aleibiri. }
$$

\begin{abstract}
The administration of any democratic state revolves around the three constitutionally recognized arms of government; the legislature, executive and the judiciary. Their relationship is very important for the actualization of the goals of the state. However, this relationship is more pronounced between the executive and the legislature as both appear to belong to political parties and are elected by the electorates. Executive/legislative relationship most times appears conflictual and in some cases cooperative. The study examines the executiveflegislative relationship in Bayelsa State to determine the nature and the issues and challenges in their relationship during Henry Seriake Dickson administration. To achieve the objective of the study, two research questions were formulated to guide the study. System theory was used as framework for analysis. The study draws its arguments basically from secondary source hence content analysis research design was used to analyze the secondary data. The findings revealed that the executive dominated the legislature in their relationship under Henry Seriake Dickson's administration which weakened the ability of the legislators to effectively perform their duties as the representatives of the people. It was also revealed that the unprofessional and inexperience of the legislators also affected their ability to effectively perform their duties which affected the social, economic and political development of the state. In the light of the above, the study recommends amongst others that the legislature should wake up to their responsibility as the watchdog of the executive and effectively monitor the activities of the executive in order to ensure good governance in Bayelsa State. More experienced people should be elected to the legislature to curtail the excesses and the continued dominance of the executive on the legislature and other institutions of government.
\end{abstract}

Keywords: Executive, Legislature, Executive Dominance, Cooperative Relations. 


\section{INTRODUCTION}

The mechanism of modern government revolves around three distinct arms of government: the executive, the legislature and the judiciary. In Nigeria, the executive and the legislative arms of government are elected through popular vote. Thus, it is pertinent to build a workable synergy and desirable relationship between the executive and the legislature in the administration of the state that could usher in peace, security and good governance. The essence is to enhance good neighborliness, corporate governance as well as institutionalize the tradition of global best practices between the two arms (Esidence \& Onyebuchi, 2013:15; Igbokwe-Ibeto \& Anazodo, 2015:15).

The President or Governor appoints cabinet members, i.e. ministers or commissioners and special advisers amongst others. Their nomination must be approved by the legislature before they can assume their respective offices. Therefore, it is apparent that non-legislative approved appointments and policy of government are considered as illegitimate and unconstitutional (Ajayi, 2012:78).

Be that as it may, it is interesting to note that government is an organic whole with shared responsibility; despite the fact that the primary function of the legislative arm is to enact law and as well as amend laws, and the executive arm to formulate and implement policies of government, there are oversights and overlapping functions carried out by the two arms that border on democratization, good governance, security, economic prosperity, human rights, and the general welfare of the citizenry (Igbokwe-Ibeto \& Anazodo, 2015:15).

Thus, the primacy of executive-legislative relations cannot be overemphasized. They are interdependent, and have boundaries as a system. It is on this premise that this paper intends to examine their relationship in Bayelsa State.

\section{STATEMENT OF PROBLEM}

Fundamentally, the three arms of government, though separate in their functions as propounded by Montesquieu in his theory of separation of powers; yet interrelate in the execution of their functions to ensure checks and balances which help to promote good governance and bring in dividends of democracy to the people (Igbokwe-Ibeto\& Anozodo, 2015:14).

Be that as it may, the legislature as the direct representatives of the citizens is not meant to be an appendage of the executive by always affirming and approving all executive requests. The legislature is obliged to ask question to ensure that executive actions and policies correspond to the yearning of the people, and is in line with the constitution. However, experience has shown that when the legislature asks such questions, it is often misconstrued as confrontation. More often than not, it results to friction and mutual distrust between the two arms. It manifested under the presidency of Olusegun Obasanjo and the National Assembly where the executive always want to dominate the legislature which led to frequent change of leadership in the National Assembly, especially in the Senate (Igbokwe-Ibeto \& Anazodo, 2015:14).

The D.S.P Alamieyesigha's administration relationship with the legislature also experienced the same situation where the executive always feels superior to the legislature which led to loggerhead with the State House of Assembly particularly with the then Speaker of the House Heineken Lokpobiri (Etekpe, Okolo \& Igali, 2015:18). 
This same scenario also played out in Seriake Dickson's administration as Governor of Bayelsa State where the executive exerted its dominance on the legislature. For example, a bill for the establishment of University of Africa in the home town of the Governor was passed into law within 24 hours. This bill was passed into law when the state owned Niger Delta University was on strike for over three months due to non-payment of staff salaries for six months. Despite the public outcry against the bill, the legislature went ahead and passed the bill into law (Odinkalu, 2016:1).

The problem, therefore is: how can the legislature as the representatives of the people overcome the executive dominance and interference in the legislative activities in order to maintain a balanced relationship?

\section{RESEARCH QUESTIONS}

The following research questions were asked in order to achieve the objective of the study.

(i) What was the nature of the relationship between the executive and the legislature during Seriake Dickson's administration in Bayelsa State?

(ii) What were the issues and challenges in the executive/legislatve relations during Seriake Dickson's administration?

\section{OBJECTIVE OF THE STUDY}

The objective of this study is to examine the executive/legislative relationship in Bayelsa State under Governor Henry Seriake Dickson's administration. The specific objectives are to:

(i) Examine the nature of relationship between the executive and the legislature in Seriake Dickson's administration.

(ii) Examine the issues and challenges in the executive/legislative relations during Seriake Dickson's administration.

(iii) Proffer measures for harmonious relationship between the executive and the legislature for subsequent administrations in Bayelsa State and Nigeria in general.

\section{CONCEPTUAL REVIEW/THEORETICAL FRAMEWORK}

\section{LEGISLATURE}

The term "legislature" is the general name given to that arm of government empowered by the constitution to make and amend laws. It is the law/rule making organ of any government especially in a democracy.

According to Agi (2006), cited in Achu (2018:194) "the term legislature is a general name for what is referred in certain context as parliament (from the medieval French Parliament, Legislative Council, Congress, National Assembly, House of Assembly and Presidium).The legislature is a body elected by the people at relatively frequent intervals, to make and amend laws". The term legislature is used for the law making body, and it is made up of people that have been chosen or elected to represent the various sections of the community (Ndoh, 2009:30). 
The legislature bears different domestic nomenclature in different countries; in the United States of America (U.S.A) it is referred to as Congress; in Nigeria it is called National Assembly at federal level and House of Assembly at the state level. In Republic of South Africa, Great Britain and Australia, it is known as Parliament (Achu, 2018:195).

\section{FUNCTIONS OF THE LEGISLATURE}

(i) Law Making: The classical theory of representative government empowers the legislature to make and amend laws. They examine and discuss in details bills on various subjects that are brought before them. They possess the constitutional powers to repeal, alter or add to the provisions of existing laws and make them applicable to changing conditions.

(ii) Control of Public Fund: In every modern democracy, the legislature holds the basic financial power. The legislature appropriates and controls public expenditures, approve state budget among others. This goes to show that public money cannot be raised or spent without legislative approval (Ajayi, 2012:78).

(iii) Oversight Function: The legislature acts as a watchdog to curb the excesses of the executive to ensure good governance. This can be achieved through impeachment proceedings against the executive if found guilty of gross misconduct. Such action is not meant to witch-hunt the executive but to promote good governance and accountability (Ubani, Nwaorgu \& Ehiodu, 2010:175).

\section{EXECUTIVE}

In the words of Obiekeze \& Obi (2004:18), the executive is simply the organ of government that is saddled with the responsibility to formulate and implement policies and programmes of government. This power revolves around all ministries, departments and agencies.

Anyanjor (2010), cited in Dimkpa (2018:213) opines that the executive arm of government is that branch of the government which has the constitutional power to implement the laws made by the legislative arm for the welfare of the citizens. In a similar vein, Nwizu (2002:101) describes the executive as a person or group of persons responsible for policy formulation and implementation. Arising from the above definitions, the executive is the arm of government that is responsible for policy making and implementation of policies and laws made by the legislature in a state.

\section{FUNCTIONS OF THE EXECUTIVE}

Following are the general functions of the executive in any giving state or country.

(i) Execution of Laws: The primary responsibility of the executive is to execute the laws made by the legislature. When the legislature make the laws, it is the duty of the executive to ensure that these are carried out and obeyed by the citizens.

(i) Formulation and implementation of Policies: Another fundamental function of the executive is to formulate policies and programmes and ensure that these policies and programmes are implemented through the various ministries, departments and agencies of government. In other words, executive carry out the day to day administration of the state. 
(iii) Another important function of the executive is the power to grant pardon, amnesty to convicted persons and can reduce sentences for convicted persons.

(iv) Diplomatic Function: The executive also has the constitutional power to represent the country in international level and can conclude state treaties. However, in most countries, such treaties must be approved by the legislature in order to have legal backing.

(v) The executive exercises military powers of the state which includes power to declare war. In Nigeria for example, the President is the Commander In-Chief of the Armed forces (Dimkpa, 2018: 215).

\section{The History Bayelsa State}

Bayelsa State is located in the Niger Delta region within the South-South Geo-Political Zone of Nigeria. It is bordered on the East by Rivers State, on the South by Atlantic Ocean and on the West by Delta State. Bayelsa State was created out of the present Rivers State by General Sani Abacha on the $1^{\text {st }}$ of October, 1996 (Etekpe, 2007:1).

The name 'Bayelsa' is an acronym of three former Local Government Areas; Brass, Yenagoa, and Sagbama in the then Rivers State. The then Brass Local Government Area is the present Nembe, Brass and Ogbia Local Government Areas. The then Yenagoa Local Government Area consists of the present Yenagoa, Kolokuma/Opokuma and Southern Ijaw Local Government Areas, and the then Sagbama Local Government Area is the present Sagbama and Ekeremor Local Government Areas. The four main languages spoken by the people of the state are Ijaw, Nembe, Ogbia and Epie-Atissa. Like the rest of Nigeria, English is the official language (Etekpe, 2007:1; Falodu, 2017:8).

Within the 24 years of existence, the state has had 5 democratically elected Governors and 4 Military Administrators. They are:

1. Navy Captain Philip Ayeni - Military Administrator, 7 October 1996 - 28 February 1997.

2. Commissioner of Police Habu Daura - Military Administrator, 28 February - 27 June 1997.

3. Navy Captain Omoniyi Caleb Olobolade - Military Administrator, 27 June - 19 July 1998.

4. Col. Paul Edor Obi - Military Administrator 19 July 1998 - 29 May 1999.

5. Dr. D.S.P Alamieyeseigha - Civilian Governor, 29 May 1999 - 09 December 2005.

6. Dr. Goodluck Ebele Jonathan - Civilian Governor, 09 December 2005 - 29 May 2007.

7. Chief Timipre Sylva - Civilian Governor, 29 May 2007 - February 14, 2012.

8. Hon. Henry Seriake Dickson - Civilian Governor 14 February 2012 - 14 February 2020.

9. Senator Douye Diri - Civilian Governor, 14 February - date.

Source: Etekpe, Okolo, \& Igali, 2015. State and government institution in Nigeria: A study of Bayelsa State House of Assembly in the Fourth Republic $1999-2012$. 
It should be pointed out that since May 29, 1999 till date, the state has been governed by the Peoples Democratic Party (PDP).

Bayelsa State House of Assembly consists of 24 members in accordance with the section 91 of the 1999 Constitution. The first Speaker of the Bayelsa State House of Assembly in the First Assembly was Rt. Hon. Heineken Lokpobiri representing Ekeremor Constituency. The process continued till the Fourth and Fifth Assembly led by Rt. Hon. Benson Friday Konbowei as Speaker of the House (Bayelsa State House of Assembly, 2020).

Rt. Hon. Tonye Isenah representing Kolokuma/Opokuma Constituency I was elected Speaker of the Sixth Assembly by members of the House in 2019. He was removed as the Speaker of the House on the ground that Senator Douye Diri, the Governorship candidate of People Democratic Party (PDP) and the Speaker are from the same local government area. His refusal to resign after several persuasion by party leaders particularly the Governor, led to his impeachment on the $30^{\text {th }}$ September, 2019. He was replaced by Rt. Hon Monday Bubou Edwin Obolo representing Southern Ijaw (Nkwazema, 2019:2). After the swearing in of Senator Douye Diri on 14 April, 2020 as Governor of Bayelsa State, Rt. Hon. Abraham Ngobere representing Brass constituency III emerged as the new Speaker of the Bayelsa State House of Assembly on the February 19, 2020 (TVC News, 2020, internet).

\section{THE NATURE OF RELATIONSHIP BETWEEN EXECUTIVE-LEGISLATIVE UNDER SERIAKE DICKSON'S ADMINISTRATION IN BAYELSA STATE}

The nature of the executive-legislative relations varies from one administration to another. However, the following are the nature of executive-legislature relationship under Seriake Dickson's administration in Bayelsa State.

\section{(i) Executive Dominance}

Executive dominance simply means a political system in which the executive behaves like a dictator owing to its strength or the weakness of the legislature. This ugly trend of domineering has eaten deep into the fabric of Nigeria's political system where the executive always feel superior to the legislature. The executive influences the legislative processes in the internal procedure and business of the house, debates and passage of bills, investigation process, scrutiny and approval of political nominees and passage of appropriation bills (Oni, 2013:200). This was the norm during Seriake Dickson's administration in Bayelsa State. For instance, the bill for the establishment of University of Africa in the home town of the Governor was passed into law within 24 hours. This bill was passed into law at a time when the state-owned Niger Delta University (NDU) had been on strike for almost three months, due the failure of the government to pay staff of the University their salary for over six months (Odinkalu, 2016:2).

\section{(ii) Cooperative Relations}

Despite the fact the executive dominated the legislature in Bayelsa State, there was cooperation between the executive and the legislature under Seriake Dickson's administration. This may be attributed to the fact that majority of the legislators were from the same party with the Governor. The result of this cooperative relationship can be seen in the areas of passage of several bills into laws. For example, the $5^{\text {th }}$ Assembly in Bayelsa State passed a total of 105 bills into law. This includes 92 executive bills and 13 private bills during the four year tenure (Independent News, Online, June 5, 2019). Other area worth mentioning is the relocation of Bayelsa State College of Education from the home of his 
predecessor Chief Timipre Sylva in Okpoma, Brass Local Government Area of Bayelsa State to Sagbama Local Government Area (Tide News Online, July 2, 2012). The Bayelsa State College of Education was not only relocated but was also renamed to Isaac Jasper Boro College of Education, Sagbama without any stiff opposition from the legislators. This shows the cordial relationship Seriake Dickson had with the legislature during his tenure.

\section{THE ISSUES AND CHALLENGES BETWEEN THE EXECUTIVE/LEGISLATIVE DURING SERIAKE DICKSON'S ADMINISTRATION}

The nature of the executive-legislative relations during Seriake Dickson's administration gave rise to the following issues and challenges discussed below.

\section{(i) Lack of Professionalism and Underdeveloped Nature of the Legislators.}

Mooney (1994), cited in Oni (2013:274) describes legislative professionalism as the enhancement of the capacity of the legislature to perform its roles in the policy making process with an expertise, seriousness and effort comparable to that of other actors in that process.

Seen in the light of the above, legislative professionalism influences the behaviour of political actors within and outside of the legislature. The degree of legislative professionalism shapes the internal structure and composition of the legislature; influence membership diversity, contributions to the legislature-executive relations (Oni, 2013:274).

Lack of these qualities amongst the legislators affects the socio-economic and political development of Bayelsa due to the inexperience of most legislators who were often handpicked by the Governor to represent the party in the general election. Their inexperience contributed to the highhandedness of Seriake Dickson's administration. For example, the legislature could not question the executive over the disappearance of $\mathrm{N} 40$ billion from the state compulsory saving fund even when such savings was backed by law; rather the legislators expressly approved 64 billion Naira loan requested by the executive in the guise of infrastructural development of the state (Odinkalu, 2016: 2). This low level of experience educationally and otherwise by the legislators is one of the major factors responsible for the underdevelopment of the state.

\section{(ii) One-Party Hegemony}

Political parties are the connecting link between divers groups of people and government and are seen to have tremendous impact on intra-arms relations in a democracy. This stems from the fact that the Chief Executive and members of the legislature belong to and emanate from political parties. Since the inception of democracy in 1999, there exists a one-party hegemony with one party in control of both the government and the State House of Assembly in Bayelsa State. Under Seriake Dickson's administration, Bayelsa State was under the control of the People Democratic Party (PDP). This one party hegemony made the executive (Governor) to behave like a dictator under a democratic setup. A good example is the pressure mounted on the former Speaker of Bayelsa State House of Assembly Rt. Hon. Tonye Isenah representing Kolokuma/Opokuma Constituency 1 to resign on the ground that Senator Douye Diri, the governorship candidate of the People Democratic Party (PDP) and the Speaker are from the same local government area. His refusal to resign after several persuasions by party leaders particularly the Governor, led to his impeachment on the $30^{\text {th }}$ September, 2019 (Punch Online, September 30, 2019). 


\section{THEORETICAL FRAMEWORK}

The study is anchored on the system theory. The system theory is a theory borrowed from the natural and physical science into management and administration. David Easton (1953) cited in Okereka \& Ogbe (2016:75) was credited as the first person to introduce system theory in political science. Easton in his "Analysis of Political Systems" presupposed that political systems are the institutions and personnel for policy-making. This includes: the chief executive, legislators, judges and bureaucrats. In the open system model, the organization interacts with the external environment and inputs are translated into output. Outputs, then, are the authoritative value allocations which constitute public policy or policies. This portrays public policy as an output of the political system (Sapru, 2013:401).

Therefore, system theory in administration and management involve the following:

(i) There should be synergy between the sub-system flow of information and other necessary instruments and there should be feedback, the result of action, which act as system control.

(ii) A system has boundaries that separate it from the environment.

(iii) It is made up of open and close systems. Open system exchanges information, energy, financial and material resources with its external environment, while closed system does not interact with its external environment but with its own environment.

Oyibo (2010:42) affirmed that "in the open system the energy inputs are taken from the external environment and converted through the process of through-put into outputs, these outputs then furnish the energy requirements for repeating the circle". For instance, public bills from the executive arm of government to the legislative arm will go through the due process of passing bill in the legislative house; it comes out as public policy (Law or Act) that satisfy the general public so as to re-energize the system (recycling).

This means that the open organizational system both in government or private sector does not exist in a vacuum. It is mutually dependent upon the external environment and it is part of the larger socio-economic system and the society. It receives input (demands, bills, information etc.) transforms them into outputs (policy, law, programmes, goods and services etc.) and exports them to the external environment. The input-output model of the open organizational system in political administrative system is shown below. 
Figure 1: The Political Administrative System

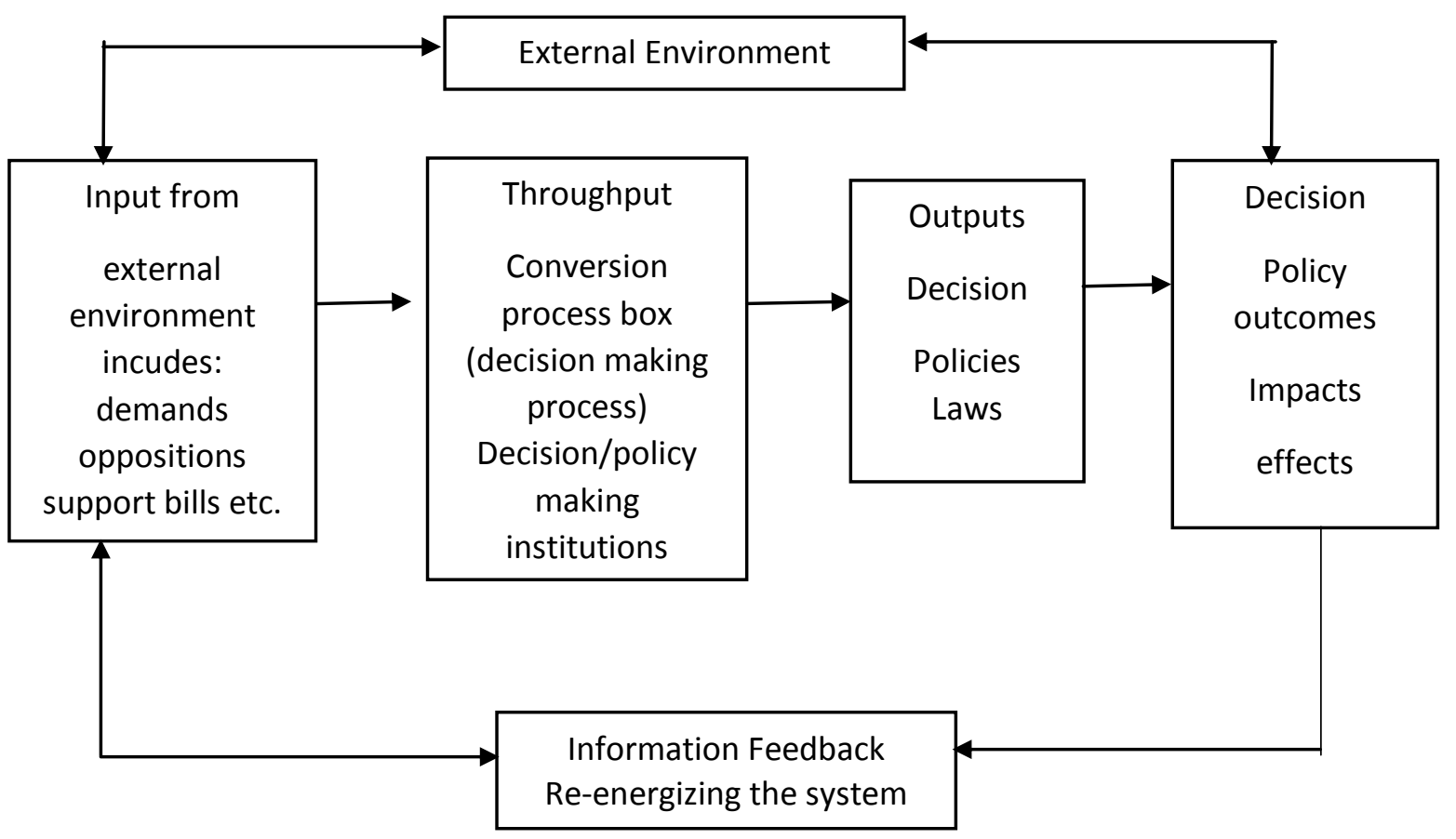

Source: Oyibo (2010:43) Culled from Koontz et al. (1980)

\section{METHODOLOGY}

The study adopted qualitative method hence content analysis research design was used for the study. This is because the researcher made use of secondary data only which include textbooks, journals newspapers and the Internet. The study therefore draws its argument mainly from secondary source thereby ruling out other method of data analysis.

\section{DISCUSSION OF THE FINDINGS}

The political landscape in Bayelsa State under Seriake Dickson's administration revealed the continued executive dominance and interference in the legislative activities of the State House of Assembly which weakened the ability of the legislators to effectively perform their fundamental roles as the representatives of the people through legislation and oversight functions. The findings also revealed that there were cooperative relations between the executive and the legislature under Seriake Dickson administration. This was due to the fact that both the executive and majority of members of the legislature are from the same party. It also revealed that the unprofessionalism and inexperience of the legislators affected the socio-economic and political development of Bayelsa State as the legislators were not able to hold the Governor accountable for some of his actions like the disappearance of 40billion compulsory saving fund for the state. Finally, the one party hegemony in the state made the executive act as a dictator in his relationship with the legislature. 


\section{CONCLUSION}

Executive/legislative relationship is a common norm in any democratic state. This is because no meaningful development can take place without a robust and cordial relationship between the two arms of government. However, experience has shown that such relationship sometimes appears to be conflictual particularly when one arm of the government feels superior and tends to dominate the other arm. This has been the case in Bayelsa State where the executive always feel superior and tend to dominate the legislature in their relationship. This scenario also played out in Henry Seriake Dickson administration where the legislature was seen as an appendage on the executive. This character of the executive in Bayelsa State under Henry Seriake Dickson administration made it difficult for the legislature to effectively discharge their duties as the representative of the people. It is against this backdrop that the study made some recommendations to ensure a healthy relationship between the executive and the legislature in Bayelsa State.

\section{RECOMMENDATIONS}

(i) The legislature should wakeup to their responsibility as the watchdog of the executive and effectively monitor the activities of the executive in order to ensure good governance in the state.

(ii) More experienced people should be elected to the legislature so as to check and curtail the excesses and the continued dominance of the executive on the legislature and other institutions of government.

(iii) Governors should allow the legislature to carry out its legislative activities without interference in order to have balanced relationship between the executive and the legislature.

(iv) Workshops and conference should be organized regularly for the legislature to help them acquire leadership and legislative skill to enable them discharge their duties effectively. 


\section{REFERENCES}

Achu, C.A. (2018). The legislature: A comparative analysis. In S.I. Ekwonna (Eds). Introduction to comparatives policies \& government. Owerri: Ambix Publishers.

Ajayi, K. (2012). The cost of law-making, governance and accountability. The legislature and executive arms in Nigeria's democracy. In H. Mohammed; M.T. Aluaigba, \& A Kabar (Eds). Corruption, governance and development in Nigeria perspectives and remedies. Kano: Becons Prints and General Enterprises.

Anikeze, N.H. (2010). Administrative and management theory: Issues, concepts and applications. Enugu: John Jacob's Classic Publisher Ltd.

Araga, A.S. (2008). Public financial management in Nigeria: Principle, practices, and issues. Garki-Abuja: Premier Educational Institute.

Bayelsa State House of Assembly (2015). Speakers of the Bayelsa State House of Assembly from 1999-date. Retrieved from https://www.facebook.com>post

Dimkpa, B. M. (2018). The executive: A comparative study. In S.L Ekwonna (Eds). Introductionto comparatives policies \& government. Owerri: Ambix publishers.

Dukku, A. M. (2012). Anti-corruption strategies in Nigeria: A sociological discourse. In A .H. Mohammed; M.T. Aluigbo \& A. Kabir (ed) Corruption, government and development in Nigeria(perspectives and Remedies), Kano: Becon Prints and General Enterprises.

Esidene, E.C. \& Onyebuchi, U.R. (2013). Executive, legislature relations in parliamentary and presidential government. In Global Journal of Arts Humanities and Social Science, 1(3), 14-19.

Etekpe, A. (2007). Politics of resource allocation and control in Nigeria. The Niger Delta experience. Port Harcourt: Harey Publication Coy.

Etekpe, A., Okolo, .P.O. \& Igali, T. (2015). State and government institution in Nigeria: A study of Bayelsa State House of Assembly in the Fourth Republic 1999 - 2012. Journal of Humanities and Social Science, 20 (3),17 - 31

Falodu, K. (2017). History of Bayelsa State. Retrieved from http://www.propertypro.ng

Federal Republic of Nigeria (FRN) (1999). Constitution of the Federal Republic of Nigeria (as amended). Abuja, Government Press.

Independent News Online (2019). Fifth Assembly passes 105 bills in four years. Retrieved from https://www.independent.ng/fift-bayelsa-assembly-passes-105-bills-in-fouryears/ 
Igbokwe-Ibeto, C.I. \& Anazodo, A.O. (2015). Managing executive-legislative working relationship for good governance and service delivery in Nigeria.In Review of Public Administration and Management 4 (8), 13-24

Nkwazema, S. (2019). Why Bayelsa Assembly enthrone new speaker. Retrieved from https://www.thisdaylive.com

Nwizu, G. (2002).Studies in modern public administration. Enugu: NGIB Publisher.

Obikeze, S.O. \& Obi, E. A. (2004). Elementary structure and organisation of government. Onitsha: Bookprints.

Odinkalu, C. (2016). The failure of State legislatures: A view from Bayelsa. Retrieved from https://www.africaresearchinstitute.org.

Okeke, M.I. (2001). Theory and practice of public policy analysis: The Nigerian experience. Enugu: Bismark Publications.

Okereka, O.P; \& Ogbe, E.H. (2016). Electoral malfeasance and the impact on political reengineering in Nigeria: Understanding the correlates. In C. Ewhrudjakpor: F.A Sanbi \& S.O. Ogege (Eds.). Town and gown: The reciprocal linkage for Nigeria's development. Abraka: Grace Communication International.

Oni, S. O (2013). Legislature-executive relations in the presidential system: A study of Lagos and Ogun State, Nigeria, 1999-2011 (Doctoral dissertation) Covenant University, Ota Ogun State: Nigeria.

Oyibo, E.E. (2010). Organization and management of health services in Nigeria: The state of art. Lagos: Amfiton Prints \& Computers.

Punch Online (2019) Bayelsa speaker impeached. Retrieved from https://punchng.come/breaking-bayelsa-speaker-impeached/

Sapru, R.E. (2013). Administrative theory and management through ( $3^{\text {rd }}$ ed). New Delhi: PHI Learning Private Limited.

TVC News (2020). Bayelsa State House of Assembly elects Abraham NIgbobere as its newspeaker. Retrieved June 8, 2020, from https://www.tvcnews.tv

The Tide News (2012). Dickson relocate C.O.E to Sagbama. Retrieved from https://thetidenewsonline.com/2012/07/02/dickson\%E2\%80\%99s-relocates-coe--tosagbama/

Ubani, E.O; Nwaorgu, O.C. \& Ehiodu. C.C. (2010). Nigerian government and administration:Issues and concepts. Aba:Cheedal Global Print .Ltd. 